\title{
土木学会論文報告集
}

第 259 号・1977 年 3 月

\section{モルタル目地を用いた PC 接合桁の破壊耐力と 変形飞関する考察 \\ STUDIES ON ULTIMATE STRENGTH AND DEFORMATIONS OF PRESTRESSED CONCRETE JOINTED GIRDERS USING MORTAR FILLER}

\author{
小 林 和 夫* \\ By Kazuo KOBAYASHI
}

\section{1. 序}

近年，プレキャストコンクリート部材を現場で架設・ 接合し一体化する工法が多方面に採用されている.この 場合の接合方法には種々あるが，プレキャスト部材間に モルタルやコンクリートの目地材を充填し, プレストレ スを与えて接合する方法は従来代表的なものの 1 つであ る.

本論文はモルタル目地を用いプレストレスで接合した 種々の構造のうち桁を対象とし, 接合部の応力, 破壊耐 力,変形に関してとくに以下の点を考察したものである.

このような接合工法では, 施工上からプレキャスト材 の強度より弱いモルタルが目地に用いられる場合があ る. また，たとえば P C 桁を橋脚上に並べ, 負モーメン 卜域の中間支点上に鉄筋や P C ロッドを配置して床版部 ならびに P C 析間の間隙のコンクリートを打設する連続 合成析の現場打ちコンクリートの強度は P C 桁よりかな り小さい場合が多い。この場合の中間支点部でも同様の ことがいえる.このように目地材の強度がプレキャスト 材の強度より小さい接合部に曲げモーメントあるいはそ れと軸力が作用するときの終局耐力については接合部の 圧縮強度の取扱いが重要であるが, 従来明確ではない。 そこで, 接合供試体の圧縮試験を行い, 目地厚と関連さ せてその取扱いを考察して強度推定法を検討した. さら に, この結果に基づいて単純桁の曲げ試験から得られた 接合部の曲げ破壊耐力を考察した.

また，プレキャスト材と目地材の特性に差異があると き, 接合部近傍の応力に及ぼすその影響の有無を調べ た.

一方, 接合面の引張付着強度は実際の施工では期待で きないので, 一体断面のひびわれ発生モーメントより小 さいモーメントで接合面が開口する.ここでは, ひびわ

\footnotetext{
* 正会員 工博 岐皁大学助教授 工学部土木工学科
}

れ幅からその面の 回転変形を求める方法 ${ }^{11}$ 亿着目して目 地を有する妳 (以下に接合桁という) と有さない桁（以 下に一体桁といら) のたわみ，連続桁とした場合のモ一 メント再分配の相違を考察した. この場合, 接合面の作 用モーメントが開ロモーメントと一体析のひびわれモー メントの間の時は両桁のたわみ, モーメント再分配特性 の差異は接合面の回転変形のみに関係するであろう．こ れに関連するものに， R C 柱とはりをプレストレスで接 合したラーメンの隅角剛度を取扱った貴重な 報告2)があ る.しかし, 破壊時までに接合部のモーメントが一体断 面のひびわれモーメントより大きくなる場合は, 対応す る位置の一体桁断面のひびわれ発生による回転変形も考 虑する必要があるう.ここでは, 後者まで含めた取扱に ついて検討した.

\section{2. 試 験 概 要}

\section{（1）供 試 体}

図一1(1) の単純桁と図一2 の角柱の圧縮試験によっ て種々の目地厚に対する接合部の破壊耐力を検討すると ともに桁の接合部近傍の応力, 前記の回転変形とたわみ を調べた. 次に，図一1(2) の連続桁で接合部の存在と モーメントの再分配の関係を調べた.

単純桁はプレキャスト材と目地材の圧縮強度の大小関 係で A，B タイプの 2 形式とした. A と B タイプの相 違はそれぞれ目地材の強度がプレキャスト材より小さい もの,同等以上のものである.プレキャスト材のコンクリ 一トと目地材に用いたモルタルの配合は 表一3 (1)，(2) に示すとおりである.これらは比較用の一体析と同様に 上縁で $0 \mathrm{~kg} / \mathrm{cm}^{2}$, 下縁で $100 \mathrm{~kg} / \mathrm{cm}^{2}$ のプレストレスを 与えて接合した. 単純桁は合計 54 本で, その種類, プ レキャスト材と目地材の力学的性質, 接合・載荷位置を 表一1, 図一1(1) に示す. 
(1) A タイプ

\section{表-1 単純标}

\begin{tabular}{|c|c|c|c|c|c|c|c|c|c|c|c|c|}
\hline 供試体の & \multirow{2}{*}{$\begin{array}{l}フ^{\circ} \quad \text { } \\
\text { キャスト } \\
\text { 配 合1) }\end{array}$} & \multirow[b]{2}{*}{$\begin{array}{l}\text { 目 地 部 } \\
\text { 配 合1 }\end{array}$} & \multirow[b]{2}{*}{$\begin{array}{c}\text { 目 地 厚 } \\
(\mathrm{cm})\end{array}$} & \multirow{2}{*}{$\begin{array}{c}\text { 接合位置 } \\
\text { と } \\
\text { 載荷方法 }\end{array}$} & \multicolumn{4}{|c|}{ プレキ+スト部3) } & \multicolumn{4}{|c|}{ 部3) } \\
\hline 種 類 & & & & & $\begin{array}{l}\text { 生縮強度 } \\
\left(\mathrm{kg} / \mathrm{cm}^{2}\right)\end{array}$ & $\begin{array}{l}\text { 引張強度 } \\
\left(\mathrm{kg} / \mathrm{cm}^{2}\right)\end{array}$ & $\begin{array}{c}\text { 弾性係数 } \\
\times 10^{5} \\
\left(\mathrm{~kg} / \mathrm{cm}^{2}\right)\end{array}$ & $\begin{array}{c}\text { ポアソン } \\
\text { 比 }\end{array}$ & $\begin{array}{l}\text { 圧縮強度 } \\
\left(\mathrm{kg} / \mathrm{cm}^{2}\right)\end{array}$ & $\begin{array}{l}\text { 引張強度 } \\
\left(\mathrm{kg} / \mathrm{cm}^{2}\right)\end{array}$ & $\begin{array}{c}\text { 弹性係数 } \\
\times 10^{5} \\
\left(\mathrm{~kg} / \mathrm{cm}^{2}\right)\end{array}$ & $\begin{array}{c}\text { ボアソン } \\
\text { 比 }\end{array}$ \\
\hline \multirow{2}{*}{ Iンリーズ } & $C-1$ & M-1 & $\begin{array}{c}\overline{0} \text { 体 标 } \\
0.75,1.25 \\
2,3,5\end{array}$ & JP-1 & 656 & 30.6 & 3.67 & 0.201 & 413 & 37.9 & 2.14 & 0.211 \\
\hline & $C-1$ & $M-1$ & $\begin{array}{c}\overline{0} \text { 体 杵 } \\
2,3,1.25 \\
2,3\end{array}$ & JP-2 & 657 & 36.0 & 3.79 & 0.200 & 413 & 37.9 & 2.14 & 0.211 \\
\hline \multirow{2}{*}{ IIンリーズ } & $\mathrm{C}-2$ & M-2 & 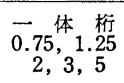 & JP-1 & 845 & 43.6 & 4.14 & 0.196 & 489 & 31.2 & 2.40 & 0.219 \\
\hline & $\mathrm{C}-2$ & $M-2$ & 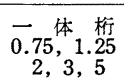 & JP-2 & 822 & 42.7 & 4.27 & 0.185 & 489 & 31.2 & 2.40 & 0.219 \\
\hline
\end{tabular}

1）表一3(1) 参照. 2 2) 図-1(1) 参照.

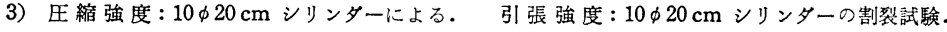
弹性係数, ポアソン比: 圧縮強度の添添 $1 / 3$ 点の圧縮応力に対するもの.

(2) B タイプ

\begin{tabular}{|c|c|c|c|c|c|c|c|c|c|c|c|c|}
\hline 供試体の & \multirow{2}{*}{$\begin{array}{l}フ^{\circ} \quad \text { } \\
\text { キャスト } \\
\text { 配 合1) }\end{array}$} & \multirow{2}{*}{$\begin{array}{ll}\text { 目 } & \text { 地 } \\
\text { 部 } \\
\text { 配 } & \text { 合 })\end{array}$} & \multirow[b]{2}{*}{$\begin{array}{c}\text { 目 地 厚 } \\
(\mathrm{cm})\end{array}$} & \multirow{2}{*}{$\begin{array}{c}\text { 接合位置 } \\
\text { と } \\
\text { 載荷方法 }{ }^{2}\end{array}$} & \multicolumn{4}{|c|}{ プレキャスト部8) } & \multicolumn{4}{|c|}{ 部 ${ }^{3)}$} \\
\hline 種 類 & & & & & $\begin{array}{l}\text { 王縮強度 } \\
\left(\mathrm{kg} / \mathrm{cm}^{2}\right)\end{array}$ & $\begin{array}{l}\text { 引張強度 } \\
\left(\mathrm{kg} / \mathrm{cm}^{2}\right)\end{array}$ & $\begin{array}{c}\text { 弾性係数 } \\
\times 10^{5} \\
\left(\mathrm{~kg} / \mathrm{cm}^{2}\right)\end{array}$ & $\begin{array}{c}\text { ボアソン } \\
\text { 比 }\end{array}$ & $\begin{array}{l}\text { 王縮強度 } \\
\left(\mathrm{kg} / \mathrm{cm}^{2}\right)\end{array}$ & $\begin{array}{l}\text { 引張強度 } \\
\left(\mathrm{kg} / \mathrm{cm}^{2}\right)\end{array}$ & 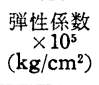 & $\begin{array}{c}\text { ボアソン } \\
\text { 比 }\end{array}$ \\
\hline \multirow{3}{*}{ エンリーズ } & $C-3$ & M-3 & $\begin{array}{c}\text { - 体 } \text { 标 } \\
0.75,1.25 \\
2,3\end{array}$ & JP-1 & 470 & 25.3 & 3.85 & 0.190 & 505 & 25.1 & 2.59 & 0.211 \\
\hline & $C-3$ & M-3 & $\begin{array}{c}\overrightarrow{0}_{0.75} \text { 体 } 1.25 \\
2,3\end{array}$ & JP-2 & 484 & 27.9 & 3.99 & 0.190 & 505 & 25.1 & 2.59 & 0.211 \\
\hline & $\mathrm{C}-3$ & $\mathrm{M}-3$ & $\begin{array}{c}\overline{0.75}, 1.25 \\
2,3\end{array}$ & JP-3 & 430 & 30.7 & 3.76 & 0.164 & 455 & 24.6 & 2.46 & 0.196 \\
\hline \multirow{3}{*}{ IIンリーズ } & $C-3$ & $M-4$ & $\begin{array}{c}\overrightarrow{0}_{0.75}, 1.25 \\
2,3\end{array}$ & JP-1 & 400 & 25.7 & 3.47 & 0.184 & 595 & 28.6 & 2.85 & 0.196 \\
\hline & $\mathrm{C}-3$ & $\mathrm{M}-4$ & 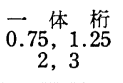 & JP-2 & 475 & 27.5 & 4.09 & 0.179 & 649 & 25.3 & 2.96 & 0.207 \\
\hline & C-3 & M-4 & $\begin{array}{c}\overline{0}_{0.75} \text { 体 } 1.25 \\
2,3\end{array}$ & JP-3 & 461 & 29.1 & 3.73 & 0.175 & 640 & 25.3 & 2.96 & 0.207 \\
\hline
\end{tabular}

1）表-3(2) 参照. 2）図一-1(1) 参照.

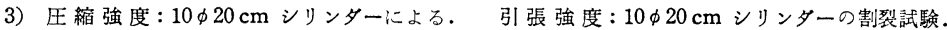
弾性係数,ポアソン比: 圧縮强度のほ结 $1 / 3$ 点の王縮応力に対するもの.

表一2 連続桁の種類と破壊荷重

\begin{tabular}{|c|c|c|c|c|c|c|c|c|c|c|c|}
\hline \multirow[b]{2}{*}{ 供試 体 } & \multicolumn{3}{|c|}{ プレキャスト部 ${ }^{1)}$} & \multicolumn{3}{|c|}{ 目 地 部1) } & \multirow[b]{2}{*}{ PC鋼材量 } & \multirow{2}{*}{$\begin{array}{l}\text { プレス } \\
ト レ ス \\
\left(\mathrm{~kg} / \mathrm{cm}^{2}\right)\end{array}$} & \multirow[b]{2}{*}{ 接合位置 } & \multicolumn{2}{|c|}{ 破壊 荷重 } \\
\hline & $\begin{array}{l}\text { 王縮強度 } \\
\left(\mathbf{k g} / \mathrm{cm}^{2}\right)\end{array}$ & $\begin{array}{l}\text { 引張強度 } \\
\left(\mathrm{kg} / \mathrm{cm}^{2}\right)\end{array}$ & \begin{tabular}{|l} 
弾性係数 \\
$\times 10^{5}$ \\
$\left(\mathrm{~kg} / \mathrm{cm}^{2}\right)$
\end{tabular} & $\begin{array}{l}\text { 压縮強度 } \\
\left(\mathrm{kg} / \mathrm{cm}^{2}\right)\end{array}$ & $\begin{array}{l}\text { 引镸強度 } \\
\left(\mathrm{kg} / \mathrm{cm}^{2}\right)\end{array}$ & 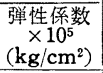 & & & & 実験值 & $\begin{array}{l}\text { 実 験值 } \\
\text { 計 算 值 }{ }^{2}\end{array}$ \\
\hline No. 1 & 581 & 37.2 & 4.04 & - & - & - & $2-\phi 12$ & 80 & 一 体 & 21.8 & 1.19 \\
\hline No. 2 & 581 & 37.2 & 4.04 & 649 & 43.8 & 3.54 & $2-\phi 12$ & 80 & 中 間 支 点 & 21.2 & 1.16 \\
\hline No. 3 & 581 & 37.2 & 4.04 & 649 & 43.8 & 3.54 & $2-\phi 12$ & 80 & 載 荷 点 & 20.8 & 1.14 \\
\hline No. 4 & 581 & 37.2 & 4.04 & 649 & 43.8 & 3.54 & $2-\phi 12$ & 80 & 中間支点載荷点 & 19.5 & 1.07 \\
\hline No. 5 & 581 & 37.2 & 4.04 & 649 & 43.8 & 3.54 & $2-\phi 12$ & 80 & 変 曲 点 & 22.0 & 1.20 \\
\hline No. 6 & 634 & 44.1 & 4.19 & - & - & - & $2-\phi 10$ & 50 & 一 体 & 15.9 & 1.13 \\
\hline No. 7 & 634 & 44.1 & 4.19 & 649 & 43.8 & 3.54 & $2-\phi 10$ & 50 & 中 間 支 点 & 16.5 & 1.17 \\
\hline No. 8 & 634 & 44.1 & 4.19 & - & - & - & $2-\phi 14$ & 110 & 一体 析 & 25.0 & 1.02 \\
\hline No. 9 & 634 & 44.1 & 4.19 & 649 & 43.8 & 3.54 & $2-\phi 14$ & 110 & 中 間 支 点 & 24.3 & 0.99 \\
\hline
\end{tabular}

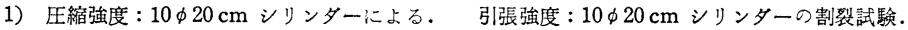

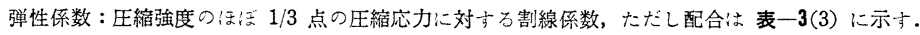

2）破壞荷重の計算值は，载荷点と中間支点に塑性ヒンジの生成を仮定した次式による極限荷重

$P_{u c}=[2 l / r(l-r)] M_{u 1}+[2 /(l-r)] M_{u 2} \quad l:$ スパン $\quad r:$ 端支点から載荷点までの距離

$M_{u_{1}}, M_{u_{2}}$ : 載荷点, 中間支点断面の極限曲げモーメントの計算值（この場合法, 目地材の压縮強度がプレキャスト材と同等以上で壳るから, $M_{u 1}, M_{u 2}$ 洨すべてプレキャスト材の強度を用いて求めた） 
一方, 連続析は目地厚 $4 \mathrm{~cm}$ でプレキャスト材と同等 以上の強度を有するモルタルを充填し, 断面図心に関し て対称に配置した 2 本の $\mathrm{P}$ C 鋼棒でプレストレスを与え た. 断面寸法, 接合位置と種類, 配合を図一1 $(2)$, 表一

2, 表一3(3) に示す.

ただし，以上のいずれの桁も一体桁に対する曲げ破壊 荷重を計算し, この時のせん断力に対して土木学会 P C 設計施工指針に基ゔいてスターラップ筋を配置した。

他方, 桁供試体のほかに目地材の圧縮強度がプレキャ スト材より小さい場合の接合部の圧縮強度の取扱いを検 討するため, 図一2 のように $10 \times 10 \times 40 \mathrm{~cm}$ の供試体 の中央部に目地材としてモルタルを配置した接合角柱を 作製して圧縮試験を行った。供試体は表一3(1) のプレ キャスト部コンクリートと目地材の配合の組合せにより Case $1(\mathrm{C}-1, \mathrm{M}-2)$, Case $2(\mathrm{C}-1, \mathrm{M}-1)$, Case $3(\mathrm{C}-$ $2, \mathrm{M}-2)$, Case 4 (C-2, M-1) の 4 種類とし, 各 Case に対して $0.75,1,1.5,2,3,5 \mathrm{~cm}$ の 6 種類の目地厚を 選定した. これと同時に, $10 \times 10 \times 40 \mathrm{~cm}$ の角柱供試体 でプレキャスト部に使用したコンクリートならびに目地 材単体の圧縮試験を実施した。

\section{(2) 使用材料}

Aタイプの単純桁と接合角柱供試体のプレキャスト部
には普通ポルトランドセメント, 木曾川産粗骨材 (最大 寸法 $10 \mathrm{~mm}$ ), 揖斐川産細骨材（最大寸法 $5 \mathrm{~mm}$ ) を用 いた。 また, 目地材には普通ポルトランドセメントなら

$$
\text { 表一3 示 方 配 合 }
$$

（1）Aタイプ単純桁と角柱圧縮試験

\begin{tabular}{|c|c|c|c|c|c|c|}
\hline 種 別 & 記号 & $\begin{array}{r}\text { 単位水量 } \\
\left(\mathrm{kg} / \mathrm{m}^{3}\right)\end{array}$ & $\begin{array}{l}\text { 単位セメ } \\
\text { ント量 } \\
\left(\mathbf{k g} / \mathrm{m}^{3}\right)\end{array}$ & $\begin{array}{c}\text { 水七メ } \\
\text { ント比 } \\
(\%)\end{array}$ & $\begin{array}{l}\text { 単位 } \\
\text { 細骨材量 } \\
\left(\mathrm{kg} / \mathrm{m}^{3}\right)\end{array}$ & $\begin{array}{c}\text { 単位 } \\
\text { 粗骨材量 } \\
\left(\mathrm{kg} / \mathrm{m}^{3}\right)\end{array}$ \\
\hline \multirow{2}{*}{$\begin{array}{l}\text { プレキャ } \\
\text { スト部 }\end{array}$} & $\mathrm{C}-1$ & 170 & 600 & 28.3 & 530 & 1080 \\
\hline & $C-2^{*}$ & 136 & 600 & 22.6 & 561 & 1139 \\
\hline \multirow{2}{*}{ 目 地 部 } & M-1 & 370 & 705 & 52.5 & 1058 & - \\
\hline & M-2 & 347 & 731 & 47.5 & 1096 & - \\
\hline
\end{tabular}

*アルキルアリルスルフォン酸塩系減水剤使用

(2) Bタイプ単純枌

\begin{tabular}{|c|c|c|c|c|c|c|}
\hline 種 別 & 記号 & $\begin{array}{r}\text { 単位水量 } \\
\left(\mathrm{kg} / \mathrm{m}^{3}\right)\end{array}$ & $\begin{array}{l}\text { 単位セメ } \\
\text { シ } / \text { 量 } \\
\left(\mathrm{kg} / \mathrm{m}^{3}\right)\end{array}$ & $\begin{array}{l}\text { 水セメ } \\
\text { ント比 } \\
(\%)\end{array}$ & $\begin{array}{l}\text { 単位 } \\
\text { 細骨材量 } \\
\left(\mathrm{kg} / \mathrm{m}^{3}\right)\end{array}$ & $\begin{array}{l}\text { 単 位 } \\
\text { 粗骨材量 } \\
\left(\mathrm{kg} / \mathrm{m}^{3}\right)\end{array}$ \\
\hline $\begin{array}{l}\text { プレキャ } \\
\text { スト部 }\end{array}$ & $C-3$ & 160 & 400 & 40 & 811 & 990 \\
\hline \multirow{2}{*}{ 目 地 部 } & M-3 & 381 & 692 & 55 & 1038 & - \\
\hline & M-4 & 335 & 744 & 45 & 1116 & - \\
\hline
\end{tabular}

(3) 連 続 林

\begin{tabular}{|c|c|c|c|c|c|c|}
\hline 種 別 & 記号 & $\begin{array}{l}\text { 単位水量 } \\
\left(\mathrm{kg} / \mathrm{m}^{3}\right)\end{array}$ & $\begin{array}{l}\text { 単位セメ } \\
\text { ント量 } \\
\left(\mathrm{kg} / \mathrm{m}^{3}\right)\end{array}$ & $\begin{array}{c}\text { 水七メ } \\
\text { シ比 } \\
(\%)\end{array}$ & $\begin{array}{l}\text { 単 位 } \\
\text { 細骨材量 } \\
\left(\mathrm{kg} / \mathrm{m}^{3}\right)\end{array}$ & $\begin{array}{l}\text { 単位 } \\
\text { 粗骨材量 } \\
\left(\mathrm{kg} / \mathrm{m}^{3}\right)\end{array}$ \\
\hline $\begin{array}{l}\text { プレキャ } \\
\text { スト部 }\end{array}$ & C-4 & 168 & 450 & 35 & 718 & 1062 \\
\hline 目 地 部 & M-5 & 300 & 750 & 40 & 1500 & - \\
\hline
\end{tabular}

(1) 单純桁
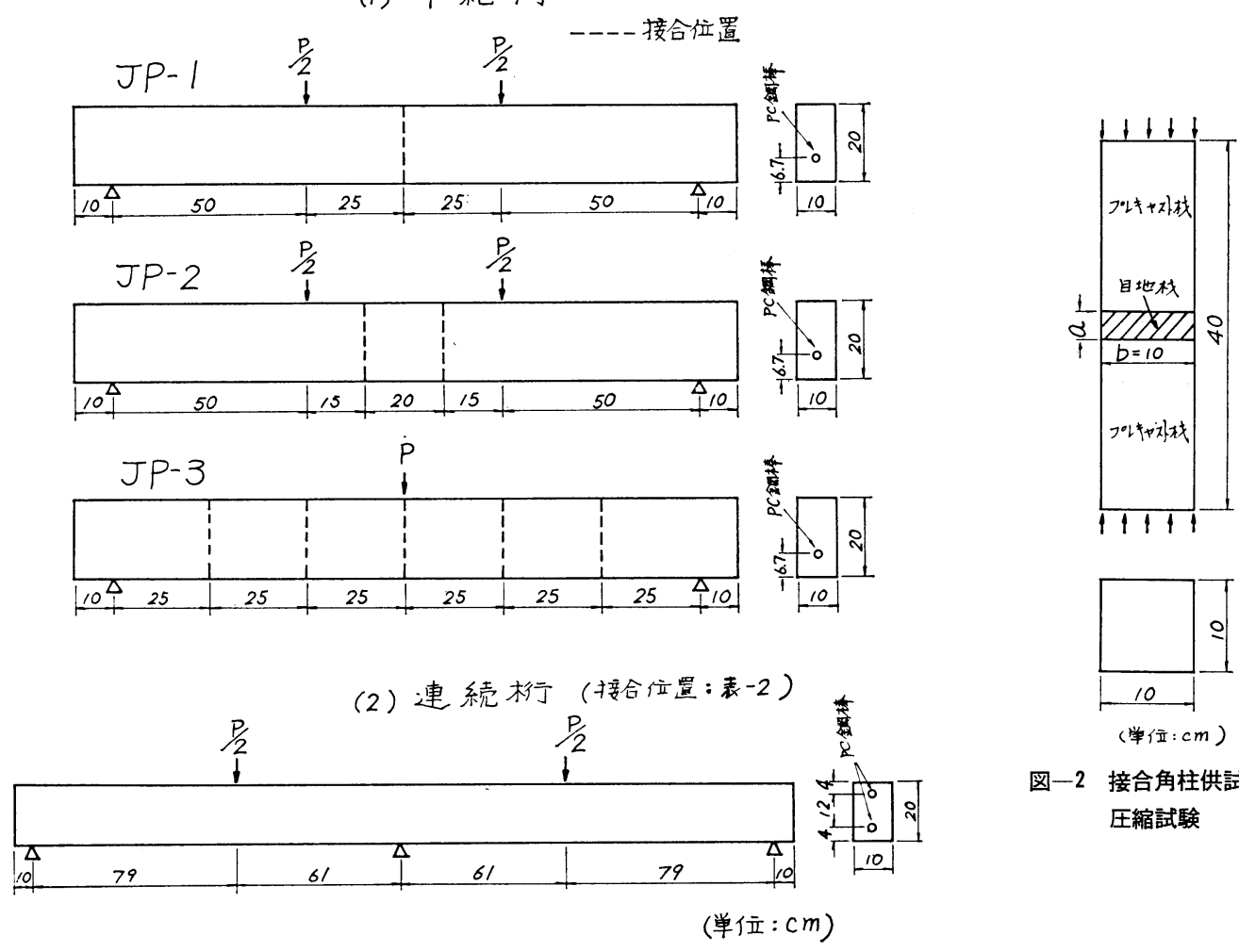

図-1＼cjkstart桁供試体の断面・寸法

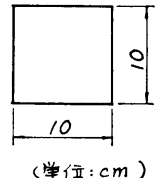

図一2 接合角柱供試体の 圧縮試験 
びにコンクリートと同一の細骨材を最大寸法 $2.5 \mathrm{~mm}$ と して用いた．一方， $\mathrm{PC}$ 鋼棒には高周波熱練社の $\phi 12$, 第 4 種, 異形鋼棒 (ウルボン), スターラップ筋と組立 筋には $\phi 6$ の丸鋼を用いた.

Bタイプの単純桁は, 目地材に早強セメントを用いた 他は上記のものと全く同じ材料で作製した.

一方, 連続桁ではプレキャスト部には普通ポルトラン ドセメント, 木兽川産粗骨材 (最大寸法 $15 \mathrm{~mm}$ ), 長良 川産細骨材 (最大寸法 $5 \mathrm{~mm}$ ) を, 目地部は早強セメン トとプレキャスト部と同じ細骨材 (最大寸法 $5 \mathrm{~mm}$ ) を 用いた. この場合の P C 鋼棒には単純桁と同一種類の $\phi 10, \phi 12 ， \phi 14$ を用い，スターラップ筋と 組立筋には $\phi 6$ の丸鋼を使用した.

\section{（3） 供試体の作製方法}

Aタイプ枌 : プレキャスト部打設 1 日脱型 6 遇 目地充填 3 週 プレストレス導入 4 週試験

$\mathrm{B}$ タイプ桁: プレキャスト部打設—旦脱型 6 週 目地充填 2 遇 プレストレス導入遇試験

連 続 桁: プレキャスト部打設—1日一脱型 6 週

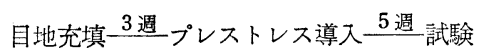
接合角柱: プレキャスト部打設—1日一脱型 6 週 目地充填— 7 異——試験

ただし，桁供試体は所定のプレストレス導入後ただち に早強セメントペーストでグラウトを行った.

以上の供試体は試験の約 1 週間前まで実験室内で湿布 養生を行った.なお，接合面はプレキャスト部の打設時 に木製の側板に接していてフラットな状態にあり，アセ トンで十分に清拭して目地を充填した。桁は取扱い上目 地の硬化をまって P C 鋼棒をスパナで軽く仮締めした.

\section{(4) 試験方法}

単純桁の載荷試験は 図一1(1) のよ5に行った。単純 桁の A タイプは最小目盛 $1 / 100 \mathrm{~mm}$ のダイアルゲージ でスパン中央と載荷点, Bタイプ桁はスパン中央のたわ みを測定した．さらに，プレキャスト部にゲージ長 30 $\mathrm{mm}$ のストレインゲージを貼布してプレストレス導入 時と載荷試験時の部材軸およびそれと直角方向のひずみ $\varepsilon_{x}, \varepsilon_{y}$ を測定し, 接合部近傍領域の応力を調べた. ま た, 回転変形を求めるためAタイプ桁では, 曲げスパン 内の側面で $\mathrm{P}$ C 鋼材位置, 上縁と下縁より $2 \mathrm{~cm}$ の位置 に $10 \mathrm{~cm}$ 間隔でプラグを貼って最小目盛 $1 / 1000 \mathrm{~mm}$ のホイットモアひずみ計で接合面の開口幅と一体析のひ びわれ幅を測定した.

一方, 連続桁は図一1(2) のように2スパンの左右対 称位置に集中荷重をかけ, ロードセルで各支点の反力を 測定し, 各荷重階の中間支点と載荷点のモーメントを求
めた.

また，接合角柱供試体の圧縮試験は図一2に示す方法 で実施した。

\section{3. 試験結果の解析と考察}

\section{(1) 接合部近傍領域の応力}

プレストレス導入時と接合面開口以前の設計荷重域内 における接合部近傍（接合面より $2 \mathrm{~cm}$ ) と少し離れた 位置 $(10 \mathrm{~cm}$ : 部材全高の $1 / 2$ に相当) のプレキャスト 部の部材軸方向応力 $\sigma_{x}$ の一例を図一 3,4 に示寸.

実駼值は $\sigma_{x}=E\left(\varepsilon_{x}+\nu \varepsilon_{y}\right) /\left(1-\nu^{2}\right)$ として求めた. た だし, $E, \nu$ は表一1 に示す圧縮強度のほぼ $1 / 3$ 点の応 カに対する割線弹性係数とポアソン比を用いた.

一方, 計算值は次式から算定したものである.

$$
\left.\begin{array}{l}
\text { プレストレス: } \sigma_{x}{ }^{\prime}=P / A+P \cdot e \cdot y / I \\
\text { 載荷による応力: } \sigma_{x}{ }^{\prime}=M \cdot y / I
\end{array}\right\}
$$

ここに, $P$ : プレストレスカ, $e:$ 断面図心からのP C

(1) 接合面的的 $2^{\mathrm{cm}}$

(2) 搂合而。 $310^{\mathrm{cm}}$

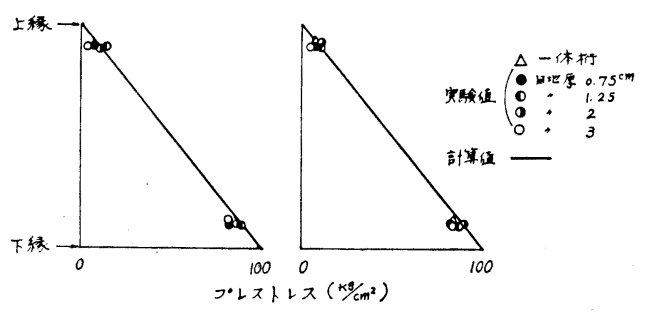

図一3 接合部周辺のプレストレス (B タイプ : IIシリーズ, JP-2)

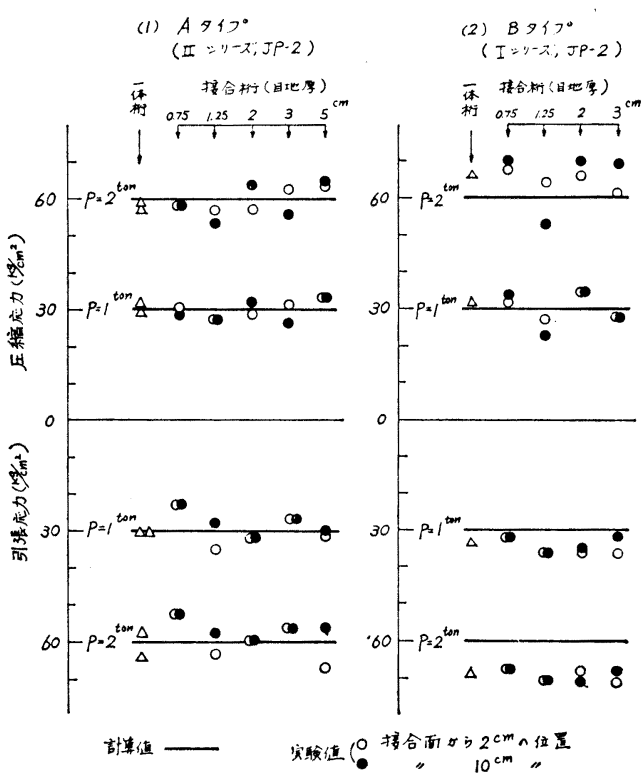

図-4 接合部周辺のプレキャスト部の曲げ応力 
鋼材の 偏心距離, $M$ : 作用曲げモーメント， $A$ : 断面 積, $I$ : 断面 2 次モーメント, $y$ : 図心からの距離

図一3,4 に示寸結果から，プレストレスならびに接合 面が開口する以前の設計荷重域内では，プレキャスト材 々目地材で弾性係数, ポアソン比が相違し, 本供試体の ように後者が前者よりポアソン比がやや大きく弾性係数 が 0.6 倍程度の時でも (表一1 参照), 接合部近傍の応 力は目地厚に関係なくその影響を無視し式 (1) で算定し て十分である.

\section{（2）接合部の破壊耐力}

\section{a) 接合部の圧縮強度}

接合角柱の圧縮試験結果を $\sigma_{c} / \sigma_{c c}\left(\sigma_{c}\right.$ : 接合部の見掛 汀圧縮強度を示し, 破壊荷重を断面積で除したもの, $\sigma_{c c}$ : プレキャスト材に用いたコンクリート単体の 圧縮 強度を示し $10 \times 10 \times 40 \mathrm{~cm}$ 角柱供試体から求めたもの) と $b / a$ ( $a$ : 目地厚, $b:$ 目地の横寸法, ここでは $b=10$ $\mathrm{cm})$ の関係で整理したものを図一5(1) に示す.なお, $b / a=0$ に対する $\sigma_{c} / \sigma_{c c}$ の值は, $10 \times 10 \times 40 \mathrm{~cm}$ 供試体 で求めた目地材単体の圧縮強度 $\sigma_{c m}$ 之 $\sigma_{c c}$ の比, $\sigma_{c m} /$ $\sigma_{c c}$ を示す. 各 Case の $\sigma_{c m} / \sigma_{c c}$ は図一5(1) に示すと おりである.

これらと同時に， $\sigma_{c m} / \sigma_{c c}=0.7$ に対して報告されて いる Summerville の試験結果 ${ }^{3)}$ を一

図一5のように, 実験結果はいずれも目地材の圧縮強 度がプレキャスト材より小さくても, 両者を接合体とし た時の接合部の見掛け圧縮強度は目地厚が減少して $b / a$ が増大すると, 目地材単体強度より次第に増加し, 目地 厚を薄くすることが得策であることを示している.

これは, おのおのを単体としてみると低強度の目地材 の方が先に破壊し, 破壊近傍域では縦のひずみとポアソ ン比が著しく大きくなる. したがって, 強度の異なる両 者の接合体を破壊まで圧縮すると目地材の横変形がプレ キャスト材に拘束されるため, 目地材は側方より圧縮応 力を受けてその見掛けの圧縮強度が増加すると考えられ る.

これは圧縮強度に及ぼす加圧板のまさつの影響奋に似 た一現象と考えられる.ここでは，両者の接合面に $\mu \sigma$ なるせん断応力が作用し, これによって目地材の横変形 が拘束されると考えて解析した。.この問題は軸対称問題 として解くことが好ましいが, 以下では便宜的に二次元 問題として取扱い，その応力と作用方向を図一6のよう に仮定した. なお, 応力は目地の中央に関して左右対称 であるから図示のように片側部のみを考え, 中央位置を $x=0$, 側面を $x=b / 2$ とする.

まず, 図一6 に示す $d x$ 間の微小要素の力のつり合い から,

$$
\left.\begin{array}{c}
a \cdot d \sigma_{l}+2 \mu \sigma \cdot d x=0, \\
\text { すなわち } \\
d \sigma_{l} / d x+2 \mu \sigma / a=0
\end{array}\right\} .
$$

一方, 側方圧縮 $\sigma_{l}$ を受ける時の圧縮強度 $\sigma$ は, 従来 の研究結果 ${ }^{5}$ を準用して近似的に次式で与えられるもの

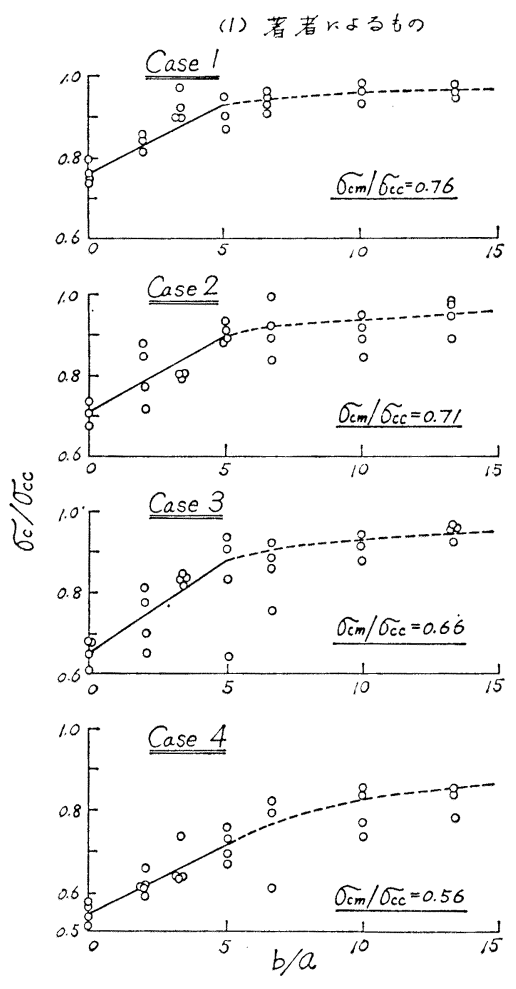

(2) Summervillerよるもの

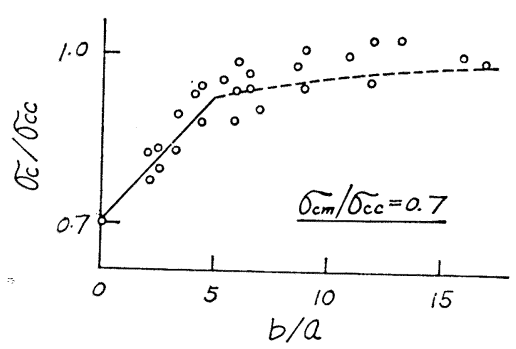

図一5 圧縮試験結果

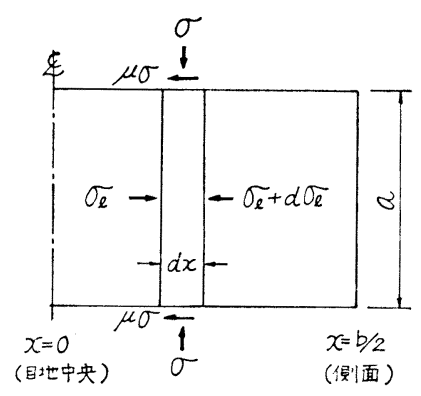

図一6 目地部の応力状態 
とする.

$$
\sigma=\sigma_{c m}+k \sigma_{l}
$$

$k$ は側方圧縮による強度の増加を表わす係数である. 式 (3)の $\sigma_{l}$ を式 (2) に代入し, $x=b / 2$ で $\sigma_{l}=0$ すな わち $\sigma=\sigma_{c m}$ なる境界条件のもとで $\sigma$ を求めると, 次 式を得る.

$$
\sigma=\sigma_{c m} \cdot e^{2 \mu k(b / 2-x) / a} .
$$

圧縮試験によって得られる強度は式 (4) の平均応力で あるから， $\sigma_{c}$ は次のようになる。

$$
\begin{aligned}
\sigma_{c} & =\int_{0}^{b / 2} \sigma d x /(b / 2)=\sigma_{c m} \cdot \frac{1}{\mu k} \cdot \frac{a}{b}\left[e^{\mu k(b / a)}-1\right] \\
& =\sigma_{c m} \cdot \frac{1}{\mu k} \cdot \frac{a}{b}\left[\mu k\left(\frac{b}{a}\right)+\frac{1}{2}(\mu k)^{2}\left(\frac{b}{a}\right)^{2}+\cdots\right]
\end{aligned}
$$

$\mu k(b / a)$ が小さい範囲では, 式 (5) の [ ] 内以近似 的には第 2 項まで採れば十分であるから，この場合の $\sigma_{c}$ は,

$$
\sigma_{c}=\sigma_{c m}\left[1+\frac{1}{2} \mu k\left(\frac{b}{a}\right)\right]
$$

あるいは， $\sigma_{c c}$ に対する比をとると次式が得られる.

$$
\sigma_{c} / \sigma_{c c}=\left(\sigma_{c m} / \sigma_{c c}\right)\left[1+\frac{1}{2} \mu k\left(\frac{b}{a}\right)\right]
$$

式 (6), (7) は $b / a$ が小さい範囲では, 目地材すなお ち接合部の見掛け圧縮強度 $\sigma_{c}$ は $b / a$ の増大とともに直 線的に増加することを示す. 実験結果でも図一5のよう におよそ $b / a \leqq 5$ の範囲では $\sigma_{c} / \sigma_{c c}$ と $b / a$ の間にこれ とほぼ同様の関係が認められ, 解析仮定がある程度当を 得たものと考えられる.

いま, 図一5 の実線のように $b / a \leqq 5$ の範囲で最小 自乗法による直線の勾配から $\mu k$ を求め, $\sigma_{c m} / \sigma_{c c}$ との 関係を示したのが 図一7 である. それによると $\sigma_{c m} / \sigma_{c c}$ が 0.5 程度以上の時は両者の関係は式 (8) で近似でき る. なお, 式 (8) は $\sigma_{c m} / \sigma_{c c}=1$ の場合は $\mu k=0$ すなお ち $\sigma_{c} / \sigma_{c c}=\sigma_{c m} / \sigma_{c c}=1$ を与える.

$$
\mu k=c\left(1-\sigma_{c m} / \sigma_{c c}\right)
$$

式 (7), (8) から $b / a \leqq 5$ の場合, $\sigma_{c} / \sigma_{c c}$ は次式から 推定しらる.

$$
\sigma_{c} / \sigma_{c c}=\left(\sigma_{c m} / \sigma_{c c}\right)\left[1+\frac{1}{2} c(b / a)\left(1-\sigma_{c m} / \sigma_{c c}\right)\right]
$$

上式の $c$ は, 本実験と Summerville の結果 (接合面 の状態は文献では不明) から, $c=1 / 2.75$ 程度と考えら れる。

なお，圧縮破壊時の接合面のせん断応力 $\tau=\mu \sigma$ は $\sigma$ に式 (4) を代入すると計算でき, $b / a \leqq 5, \sigma_{c m} / \sigma_{c c} \geqq 0.5$ の範囲では $b / a=5, \sigma_{c m} / \sigma_{c c}=0.5$ の時最大となる. い ま, $c=1 / 2.75, k$ は一般に 4 程度とみなすと, この最大 のせん断応力は $x=0 \sim b / 2$ に対して $\tau=0.085 \sigma_{c m} \sim$
$0.045 \sigma_{c m}$ となる. 打 継面の純せん断強度は 粗面では約 $0.12 \sigma_{\mathrm{cm}}{ }^{6)}$, 本試験体のようにフ ラットな時はその約 $1 / 2$ であり，接合面に 大きな圧縮応力が作用 する時は著しく增加す る)・したがって，フ

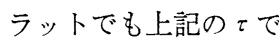
付着は阻害されないと

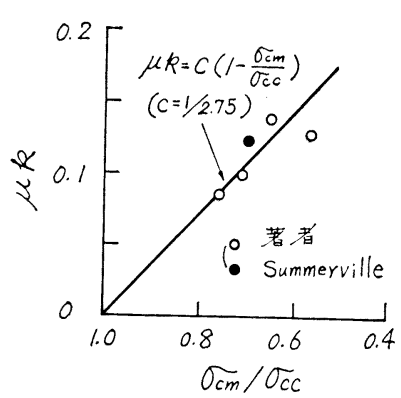

図一7 $\boldsymbol{\mu} \boldsymbol{k}$ と $\boldsymbol{\sigma}_{c m} / \boldsymbol{\sigma}_{c c}$ の関係
思われ， $c$ 值は接合面の粗滑に関倸しないであろう.

一方, $b / a>5$ では $b / a \leqq 5$ の場合に比べると, $b / a$ の増大に伴う $\sigma_{c} / \sigma_{c c}$ の増加はかなり小さくなり, 図一5 の点線のように目地厚が 0 , すなわち $b / a=\infty$ の時に $\sigma_{c} / \sigma_{c c}=1$ と考えた次の双曲線式が実験結果をかなり良 く表現している.

$$
\sigma_{c} / \sigma_{c c}=(b / a) /[(b / a)+5(1-\beta) / \beta] \text {. }
$$

ここに, $\beta$ は $b / a=5$ のときの $\sigma_{c} / \sigma_{c c}$ の值を表わす. したがって，これは式 (9) で $b / a=5$ とおいた次式から 推定できる.

$$
\beta=\left(\sigma_{c m} / \sigma_{c c}\right)\left[1+2.5 c\left(1-\sigma_{c m} / \sigma_{c c}\right)\right]
$$

b) 桁の接合部の曲げ破壊耐力

目地材の圧縮強度がプレキャスト材と同程度以上の $\mathrm{B}$ タイプの単純桁は P C 鋼材が降伏してプレキャスト部が 圧潰したのに対し, 逆のAタイプでは目地部が圧潰して 曲げ破壊を呈した。

図一8 は, 一体桁の曲げ破壊モーメント実験值 $M_{u c}$ に対する接合桁の曲げ破壊モーメント実験值 $M_{u J}$ の比 を示したものである.それによると，B夕イプでは接合 桁の耐力の低下はほとんどなく, 破壊耐力に及ぼす接合 の影響は無視できるであろう.一方, Aタイプでは目地 厚の増加に伴って耐力の減少が大きくなり, 目地材の圧 縮強度にほぼ等しい強度を有する一体桁（図一8(1))に は参考のためにAタイプの接合桁のモルタルに近い強度 を有するBタイプの一体桁の実験值を目地厚がめの時の $M_{u J}$ とみなした $M_{u J} / M_{u c}$ の值を併記した）の耐力に 漸近していく様相が認められる.

本試験結果から, 目地厚を可能な範囲で薄くしておけ ば目地材の圧縮強度がプレキャスト材より低下しても破 壊耐力の低下が軽減されることが明らかであって, 前記 の圧縮試験結果と同様なことが示される.

目地厚は部材寸法との相対值としての尺度で評価され ると考えられるが，その基準になる寸法について調べ た。

図一9 は，Aタイプ桁の破壊耐力実験值から求めた接 合部の見掛け圧縮強度と前記の圧縮試験結果の関係を示 

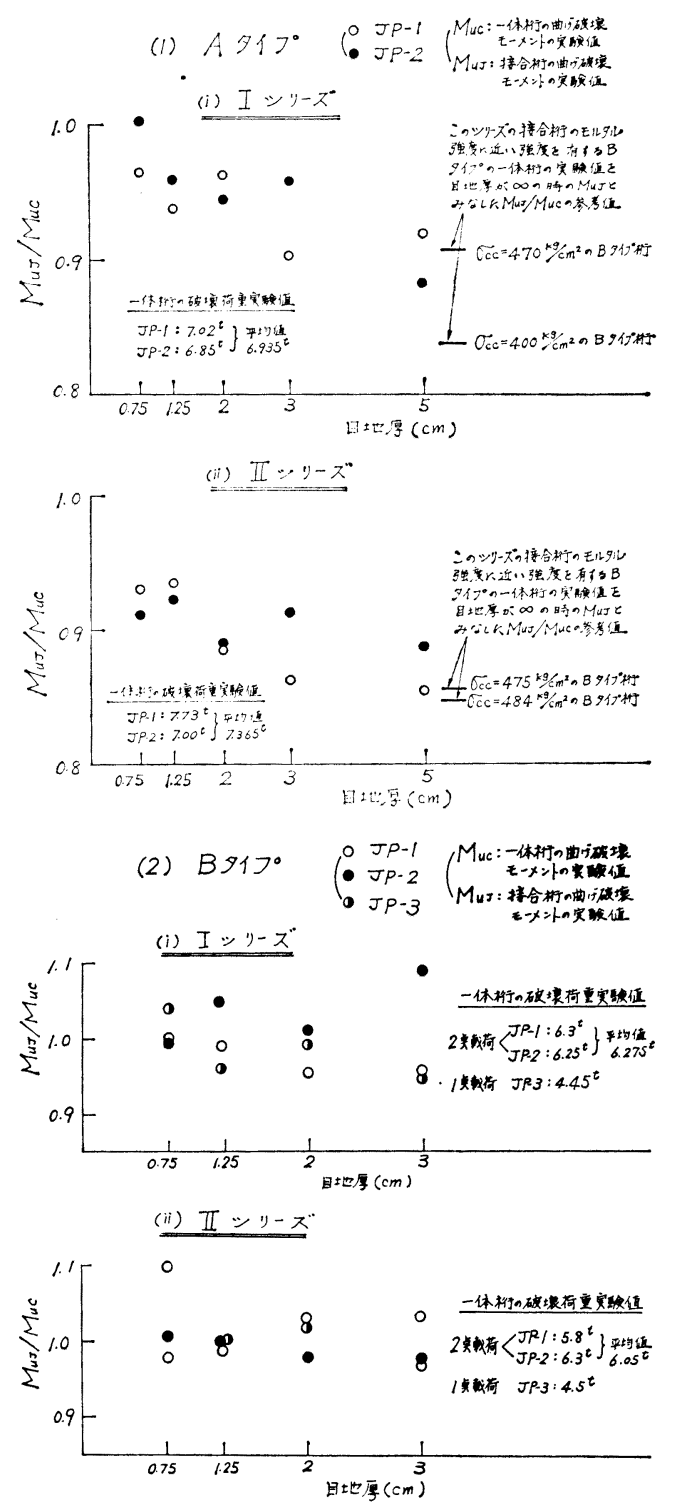

図一8 接合桁と一体桁の曲げ破壊耐力実験値の比

したものである. 前者は $M_{u J}$ と $M_{u c}$ の比から, 破壊 時の圧縮応力分布を矩形と仮定した常用の式 (12) から $\sigma_{c} / \sigma_{c c}$ を求めた.

$$
\begin{aligned}
M_{u J} / M_{u c}= & {\left[A_{p^{\sigma} \sigma_{y}}\left(d-\frac{1}{2} \frac{A_{p^{\sigma} p y}}{\alpha \sigma_{c c} B}\right)\right] / } \\
& \cdot\left[A_{p^{\sigma} \sigma_{y}}\left(d-\frac{1}{2} \frac{A_{p^{\sigma} p y}}{\sigma_{c c} B}\right)\right] \cdots
\end{aligned}
$$

ここに, $A_{p}$ : 鋼材断面積, $\sigma_{p y}$ : 鋼材降伏点, $d:$ 圧縮 縁から鋼材位置までの距離, $B$ : 断面の幅, $\alpha: \sigma_{c} / \sigma_{c c}$.

一方, 図示の実線は圧縮試験結果に基づく式(9),(10) の目地の横寸法の代わりに桁の破壊時の中立軸高さ $x_{\boldsymbol{u}}$ $=A_{p} \sigma_{p y} / \alpha \sigma_{c c} B$ を用いて, $\sigma_{c} / \sigma_{c c}$ を求めたものである.

図一9によると, 式 (12) 中の耐力算定式が近似式で

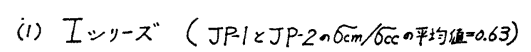

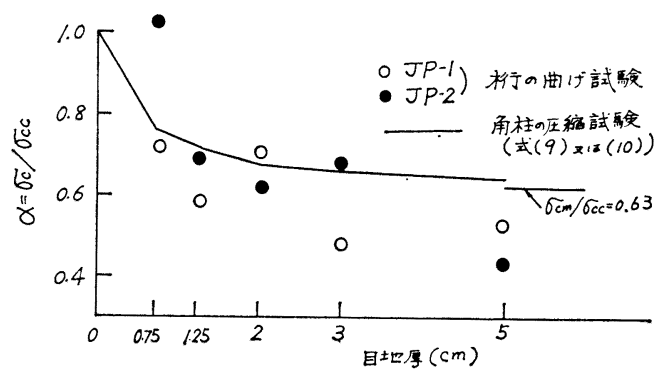

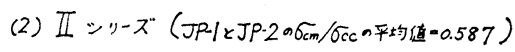

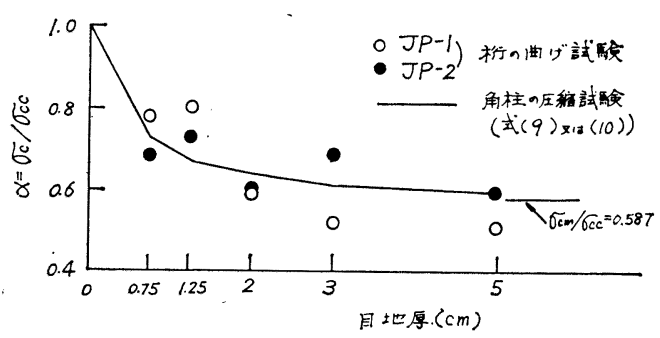

図一9＼cjkstart桁（Aタイプ）の曲げ試験と角柱の 圧縮試験結果の関係

あるため桁の耐力比から推定した $\sigma_{c} / \sigma_{c c}$ は圧縮試験結 果に基づく $\sigma_{c} / \sigma_{c c}$ と差異があるが，全体的にみると比 較的良く合致していると考えられる.このことは，接合 部の曲げ破壊耐力に及ぼす目地厚の影響を評価する際の 基準の寸法として破壞時の中立軸高を採りうるであろう ことを示している.

したがって，接合桁と一体桁の曲げ破壊耐力の 差異 は，たとえば破壊時の圧縮域形状が幅 $B$ の矩形の場合は 次式から中立軸高さ $x_{u}$ を求め, $\alpha=A_{p} \sigma_{p y} / \sigma_{c c} \cdot x_{u} \cdot B$ を式（12）に代入することによって推定することができ る.

$$
A_{p} \sigma_{p y}=\alpha \sigma_{c c} \cdot x_{u} \cdot B=f\left(x_{u} / a, \sigma_{c m} / \sigma_{c c}\right) \cdot \sigma_{c c} \cdot x_{u} \cdot B
$$

ただし， $\alpha=\sigma_{c} / \sigma_{c c}$ は式 (9) または (10)で $b / a$ を $x_{u} / a$ に置き換えればよいので, $x_{u} / a$ と $\sigma_{c m} / \sigma_{c c}$ の関数とな り $\alpha=f\left(x_{u} / a, \sigma_{c m} / \sigma_{c c}\right)$ で与えられる.

\section{（3）接合桁と一体桁の変形挙動}

a) 接合面と一体断面の回転変形

図一10 は，ひびわれ幅とたわみの測定值から求めた 回転変形間の関係を接合桁 (A タイプ, JP-1 形式) に ついて示したものである. 図示の回転変形 $\theta_{\omega}$ は $\mathrm{P} \mathrm{C}$ 鋼 材位置と下縁から $2 \mathrm{~cm}$ の位置での接合面のひびわれ開 口幅 $\omega_{1}, \omega_{2}$ より, $\theta_{\omega}=\left(\omega_{2}-\omega_{1}\right) / Z\left(Z: \omega_{1}\right.$ と $\omega_{2}$ 測定位 置間の鉛直距離) として求めた. 一方， $\theta_{\delta}$ は同一桁の たわみ測定值から 図一14 のような関係より求めた回転 
変形を示すが，これらは接合面の開口後，次に載荷点近 傍に曲げひびわれが発生したので次のように求めた。

i ）接合面開口〜載荷点近傍にひびわれが発生するま で:

$$
\theta_{\dot{\delta}}=4 \Delta \delta_{1} / l \quad l: \text { スパン }
$$

この関係は JP-1 形式では図一14 として求まる.

ii）載荷点近傍にひびわれが発生した後では：

上と同様にして,

$$
\theta_{\delta}=4 \Delta \delta_{2} / l^{\prime} \quad l^{\prime}: \text { 載荷点間の距離 }
$$

ここに, $\Delta \delta_{1}, \Delta \hat{o}_{2}$ は接合面の開口に起因するたわみの 増加量であり, 開口が起らない場合のたわみは荷重の増 大に比例して増加すると考えて実測值からその量を差し 引いたもので，それぞれスパン中央のたわみの増加量， スパン中央と載荷点下のたわみ差の増加量を示す.

図一10 から， $\theta_{\omega}$ は $\theta_{\delta}$ よりやや大きくなるが，ひび われ幅が横断方向に均一でなく表面で大きくなることが 理由の 1 つに考えられる. しかし， $\theta_{\delta} / \theta_{\omega}$ はほぼ $0.8 \sim$ 1.0 の範囲にあって両者がかなり良く合致している.し たがって, 接合桁と一体桁のたわみ, 連続桁の曲げモー メント分布の相違は, 接合面の開口以後の回転変形と一 体桁断面の回転変形の差異に基づいて解析することが可 能であろう.

そこで，ひびわれ幅測定值から求めた接合面および一 体桁の最大ひびわれ面の回転変形 $\theta$ と作用モーメント

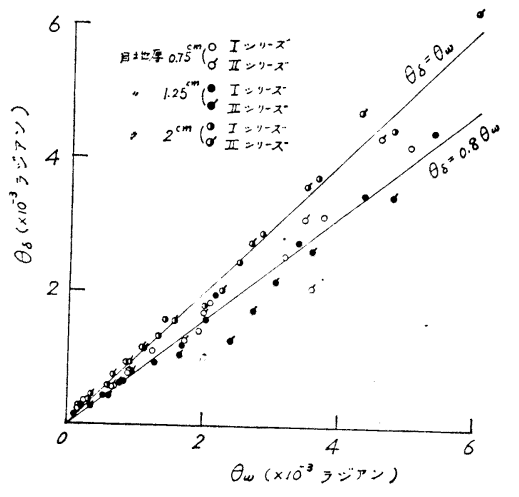

図-10 $\theta_{\delta} \sim \theta_{\omega}$ の関係

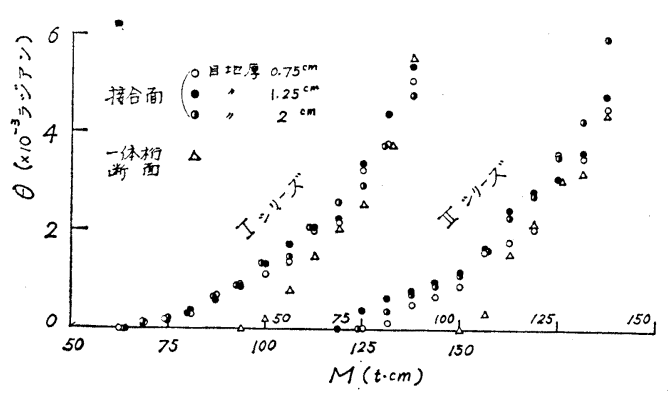

図一11 接合面と一体桁断面の回転変形（Aタイプ）
$M$ の関係を調べたのが図一11 である. 同図から，両者 の回転変形の差 $\Delta \theta$ は接合面の開口後次第に増加し, 一 体桁断面のひびわれ発生時にほぼ最大 $\left(\Delta \theta_{0}\right)$ となる. そ れ以後は近似的に $\Delta \theta_{0}$ とみなし，取扱いを簡単化する ために $\Delta \theta$ と $M$ の関係を次のように単純化して表わす ことにした.

(i ) $\quad M \leqq M_{c r 1}: \Delta \theta=0$

(ii) $M_{c r 1}<M \leqq M_{c r 2}: \Delta \theta=\Delta \theta_{0} \times\left(M-M_{c r 1}\right) /$

(iii) $M_{c r 2}<M$ $: \Delta \theta=\Delta \theta_{0}$ $\left(M_{c r 2}-M_{c r 1}\right)$

上式の $M_{c r 1}, M_{c r 2}$ はそれぞれ接合面の開口モーメン ト，一体析断面の曲げひびわれ発生モーメントを示す.

以下の b), c) のたわみ, 連続桁のモーメントの解析 にあたっては, 上の $\Delta \theta_{0}$ 法次式かか次の方法で計算し た。

$$
\Delta \theta_{0}=\omega /(d-x)
$$

ここに, $\omega: M=M_{c r 2}$ 時の接合面の $\mathrm{P} C$ 鋼材位置に おけるひびわれ開口幅, $d, x$ : 圧縮縁から $\mathrm{P} C$ 鋼材位置 および $M=M_{c r 2}$ 時の接合面の中立軸位置までの距離.

$\omega$ の算定式として，ここでは ACI 規準の基礎とさ れ，かなり一般性があると思われる次の Gergerly-Lutz 式8を用いた。

$$
\omega=1.1 K \sigma_{s} \times 10^{-6} \text { (単位: } \mathrm{kg}, \mathrm{cm} \text { ) }
$$

ここに, $K$ は断面特性による係数であり, 主筋応力 $\sigma_{s}$ は P C 断面ではプレストレスと荷重による合応力が 下縁で 0 もしくは曲げ引張強度になる時からの鋼材応力 の増加量とするが9)，接合面では前者の方が適当である.

式 (14),(15) の諸量は，P C 鋼材とコンクリートの圧 縮, 引張応力〜ひずみ関係を完全弾塑性で近似して平面 保持則と力のつり合いから求めるが, $M_{c r 2}$ 以外の接合 面に関する $M_{c r 1}, \sigma_{s}, x$ はその面の引張強度は 0 とみな して算定するのが現実的で安全であって,ここでは 0 と した.

以上のように，接合析の破壊時まで接合位置の作用曲 げモーメント $M$ が $M_{c r 2}$ より大きくならない時は接 合面の回転変形のみに注目し式 (14)のi) 〜ii) を対象と すればよいが， $M_{c r 2}$ より大きくなる時は，i） iii）の 範囲で解析する必要がある. 以下の節では後者の状態を 取上げて検討した.

b)たわみ

図一12 は荷重とスパン中央のたわみの関係を示した 一例であるが，接合桁と一体桁のたわみの差と荷重の間 には回転変形差を与える式 (14) と類似の関係が認めら れる.

さらに, 接合桁と一体桁のたわみ $\delta_{J}, \delta$ の相違の程度 を明膫にするため, 両者の比 $\delta_{J} / \delta$ を示したのが図一13 
である.図示の実験結果（各目地厚の平均值：ただし， A タイプでは, 破壊荷重が一体桁に比較的近い 0.75 , $1.25,2 \mathrm{~cm}$ の平均值) から, たわみ比は荷重レベルで変 化し一体桁の曲げひびわれ発生時付近で最大となるこ とまた開口する接合部の数と位置によって様相が異な ることが認められる。たわみに及ぼす目地厚の影響につ いては一定した傾向が認められなかった.

一方,たわみを次の方法で計算し実験結果と比較した. 一体桁のたわみ $\delta$ は, 従来 P C 断面に対して実用上 かなりの精度を有するとされる次の曲げモーメント〜曲 げ剛性 $(M \sim K)$ 関係の提案式 ${ }^{10)}$ を用い, 弾性荷重法で 計算した.

$$
\left.\begin{array}{rl}
M<M_{c r 2} & : K=K_{e} \\
M_{c r 2} \leq M \leq M_{u}: K=K_{e}-\left(K_{e}-K_{u}\right) \\
\cdot\left[\frac{2\left(M-M_{c r 2}\right)}{M_{u}-M_{c r 2}}-\left(\frac{M-M_{c r 2}}{M_{u}-M_{c r 2}}\right)^{2}\right]
\end{array}\right\}
$$

ここに, $M_{u}$ : 一体桁断面の曲げ破壊モーメントの計算 值, $K_{e}, K_{u}$ :一体桁断面の曲げひびわれ発生前の初期

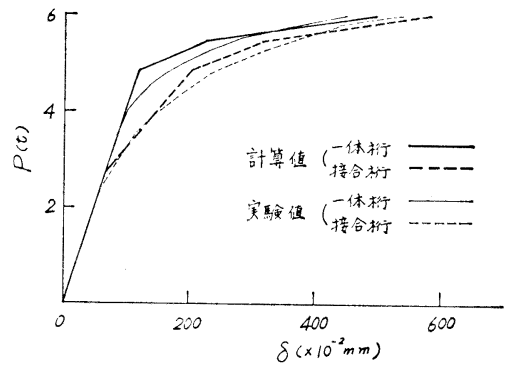

$\left(\begin{array}{l}\mathrm{A} \text { タイプ : II シリーズ, JP-2 接合椼は } \\ \text { 目地厚 } 0.75,1.25,2 \mathrm{~cm} \text { の平均值 }\end{array}\right)$

図一12 荷重〜たわみ関係
(1) $A$ タイ $フ^{\circ}$
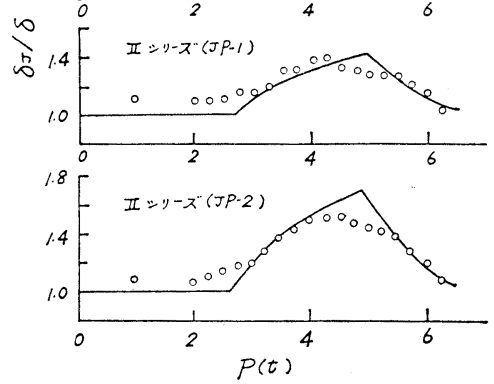

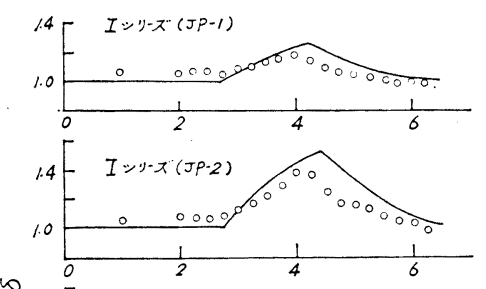

(2) B タイプ
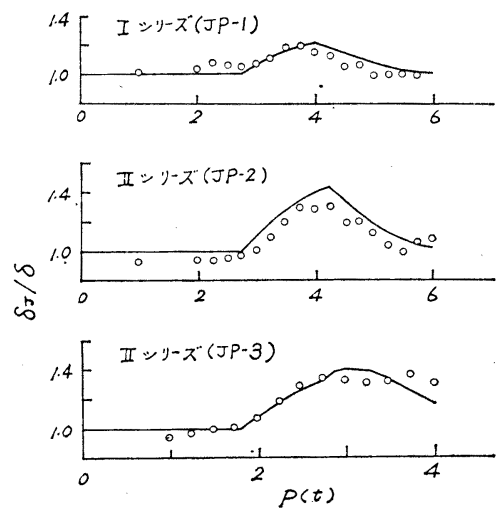

○实馬英值

計算値
曲げ剛性と破壊時の終局曲げ剛性の計算值.

接合枌のたわみ $\delta J$ は, 与えられた荷重時 の接合面の曲げモーメ ントに対して式 (14) より対応する位置の一 体桁断面に対する付加 回転角 $\Delta \theta$ を求め, 図 -14の関係から接合 面の存在に起因するた

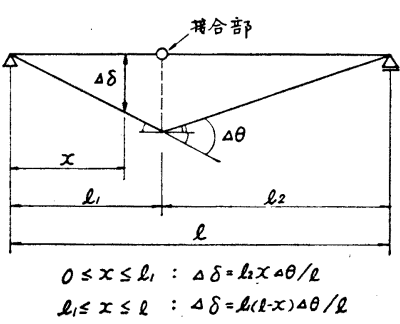

図一14 $\Delta \theta$ と $\Delta 8$ の関係 わみの増加量 $\Delta \delta$ を計算して $\delta_{J}=\delta+\Delta \delta$ とした. な掞, 図-1(1) の JP-2, JP-3 形式のように 2 箘所以上の位 置で接合した時はおのおのによるたわみの増加量を加え たものを $\Delta \delta$ とする.

図一12,13に示すように計算值は実験結果と比較的良 く合致していると考えられる。したがって，破壊までの 各荷重レベルにおける接合桁と一体桁のたわみの相違の 程度は，接合部の曲げモーメントが $M_{c r 2}$ より大きくな るような場合を含めた式 (14) 艺考慮し，ここで述べた 方法を適用することによってある程度定量的に求めるこ とが可能である。

c）接合連続枌の曲げモーメント再分配

前節のように, 接合桁と一体析の変形挙動の相違は単 純桁ではたわみの差異として現われるが，連続析ではさ らに曲げひびわれの発生以後の段階から生ずる曲げモー メントの再分配についても検討する必要がある.

図一15 は，連続桁の支点反力の測定値から荷重と載 荷点, 中間支点モーメントの関係を求め, 両桁を比較し たものである.

接合面の開口以後の荷重レベルから生ずる接合連続桁 の曲げモーメント再分配の挙動 を一体桁と比較すると, 図一15 のように接合位置に応じて異 なった様相を呈するものであっ て, 設計上何らかの定量解析が 必要である.

そこで，前に述べた接合面と 一体桁断面の回転変形の差に着 目してこれを次のような方法 で解析した。

静定基本系として中間支点を 除去した単純桁を選定し, 最初 に与荷重 $P$ に対して中間支点 反力 $R$ を任意に仮定し，これ によるスパンの曲げモーメント $M$ の分布を求める. 次に, 式 (17) から各位置の $M$ に対応す 
(1) 中閣支卓モーメント

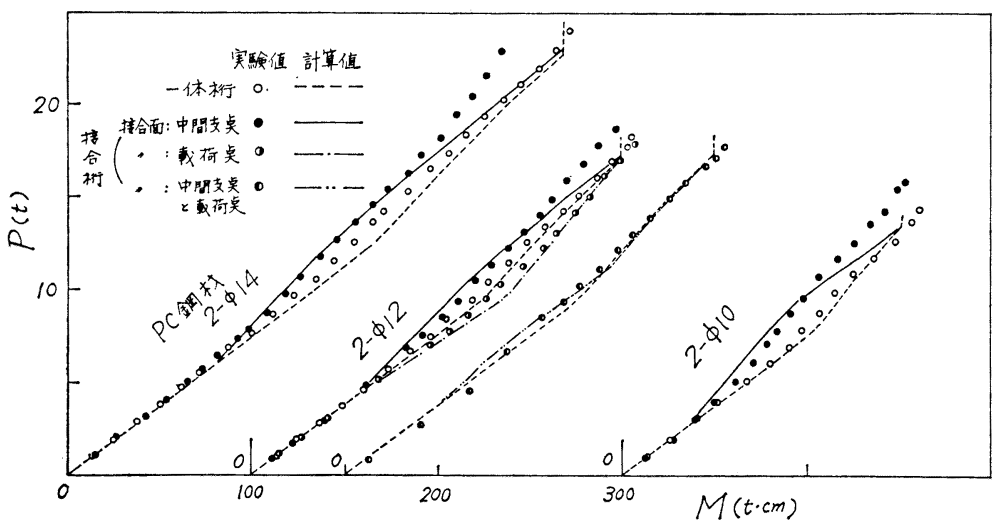

（2）載荷卓モーメント

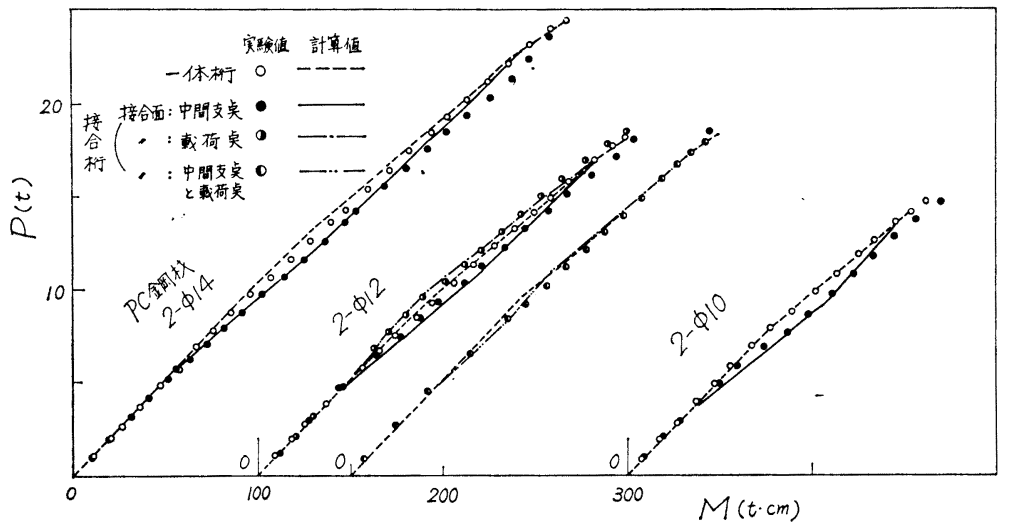

図一15連続析の荷重〜曲げモーメントの関係
て一層合理的に算定することが可 能である.

一方, 連続桁の破壊荷重は 表一

2 に示すとおりである.

表一2 から, 中間支点あるいは 載荷点に接合部を有する桁は, 一 体析ならびに変曲点に接合部を設 けた桁に比べると破壊耐力がわず かではあるが低下する傾向にあ る.しかし, 前者の場合でも極限 荷重式による計算值（表一2 の注 2) 参照）を下回るものは認めら れない.

\section{4. 結語}

本研究で得られた結果を要約す ると次のとおりである.

(1) 接合面が開口する以前の 設計荷重域内の接合部近傍の応力 は, プレキャスト材と目地材の特 性が異なり, 後者が前者よりポア ソン比がやや大きく, 弾性係数が 0.6 倍程度の時でも(表一 1 参照)， 本実験の範囲では目地厚に関倸な くその影響を無視して算定しても 実用上さしつかえないと考えられ た。

（2）目地材の圧縮強度がプレキャスト材より小さい 接合部の見掛けの圧縮強度は目地厚に関係し, その減少 とともに目地材単体強度より次第に増加する.この場合 の与えられた目地厚に対する強度の大略值は, 目地の横 寸法と目地厚の比の関数として式 (9), (10) から求めら れる。

（3）桁の接合部の曲げ破壊耐力は, 目地材の圧縮強 度がプレキャスト材と同等以上の場合には一体桁断面に ほぼ等しく，接合面の存在は開口荷重の低下をきたすが 破壊耐力にはほとんど影響しないと考えてよい。一方， 同等以下の場合は上記の圧縮強度と同様に目地厚が関倸 し，この場合の一体析に対する耐力比は目地の横寸法と して破壊時の中立軸高さを採り, 式 (9), (10) を利用し 式 (12) から推定できょう.

(4) 接合面では一体析断面よりひびわれ開口耐力が 低下し, 式（14）のように両断面の回転変形に差が生ず る. この回転変形の差に起因する接合桁の付加的たわみ を考慮することにより, 破壊までの接合桁と一体桁のた わみ比の変化の様相とその概略值を推定することが可能 のように回転変形を考慮に入れた補正を施すことによっ 
である.

（5）接合連続桁では，接合面の開口以後から生ずる 曲げモーメントの再分配が接合位置に応じて一体桁と相 違する.これは，上記の回転変形差による付加的たわみ を考慮に入れた計算法によってかなり定量的に求めう る. また，接合面が危険断面に存在する連続桁では破壊 耐力が一体桁よりやや低下寸る傾向にあったが，極限荷 重式による計算值を下回ることはなかった.

最後に，本研究を実施するにあたって暖かいご援助を いただいた 前岐阜大学教授 故大浜文彦先生に深く御礼 申し上げます。また，実験の実施とデータの整理に多大 の労をいただいた故蛭子五平, 坂 秀己君 (昭和 50 年 度卆業生), 岡田隆彦, 谷口真語君 (昭和 51 年度卆業 生）に嬮く感謝の意を表する.

なお，本解析にあたり名古屋大学大型計算機センター の FACOM 230-75 を利用したことを付記する.

\section{参考文 献}

1) Park, P. and Paulay, T. : Reinforced Concrete Struc tures -6.6 Flexural Deformations of Members-, A Wiley-Interscience Publication, John Wiley \& Sons.
2）田辺忠顕：コンクリート合成構造におけるプレキャスト 部材の利用に関する基礎的研究, 土木学会論文報告集 第 206 号, pp. 111 124, 1972 年 10 月.

3) Summerville, G. : Joint for Precast Concrete Components-Current Research on Joints-, Concrete, March 1970.

4）たとえば, 益田森治・室田忠雄 : 工業塑性力学, 養賢堂, 昭和 42 年版.

5）多数あるが，たとえば Richart, Ben-Zvi，Bellamy など の研究結果を含めて W. Martin : ACI Journal, October 1968 に記載.

6) Okada, K., Kobayashi, K. : Some Problems in the Design of Composite Beam, Journal of Japan PCEA, Special Issue for 7th FIP Congress, Vol. 16 Extra Number 1974.5.

7）畑野 正: 打ち継ぎコンクリートの剪断強度に就いて, 電力技術研究所所報, 土木第 1 巻第 6 号, 昭和 24 年 5 月.

8) B. Bresler: Reinforced Concrete Engineering, Vol. 1, -4.7 Influence of Bond in Control of Cracking -, A Wiley-Interscience Publication, John Wiley \& Sons.

9) ACI Committee 224: Control of Cracking in Concrete Structures, ACI Journal, December 1972.

10）坂・岡田・六車：プレストレストコンクリート，朝倉書 店.

(1976.7.26 - 受付) 